\title{
Chronic Inhalant Dependence With Early Onset Cognitive Impairment, Depression and Psychotic Disorders: A Case \\ Report
} Mehmet Hamid Boztaş', Çiğdem Çiftçi Kaygusuz ${ }^{2}$, Özden Arısoy', Safiye Gürel ${ }^{3}$

'Asist. Prof. Dr., ${ }^{2}$ Dr., ${ }^{3}$ Assoc. Prof. Dr., Abant izzet Baysal University izzet Baysal Medical School,

\section{ABSTRACT}

Chronic inhalant dependence with early onset cognitive impairment, depression and psychotic disorders: a case report

Inhalant substance dependence is generally seen at 14-15 years of age and its prevalence decreases in adulthood. Inhalant use is common among disadvantaged groups, street children, people with history of crime, depression, suicide, antisocial attitudes, history of abuse, violence and any other drug dependence. Psychosocial factors are important in the beginning of inhalant dependence. Medical and neurological problems are frequently seen in chronic inhalant users. The duration of inhalant use is positively correlated with morbidity and mortality.

In this report, medical and neuropsychiatric results of chronic inhalant dependence will be discussed. In our patient, chronic inhalant use caused central and peripheral neuropathy, cognitive impairment, depression, psychotic disorder, upper motor neuron type destruction in muscles and mild anemia. Neuropsychiatric destructive effects are prominent in chronic abuse. Mirtazapine and olanzapine treatment decreased depressive and psychotic symptoms, but cognitive impairment, neuropathy, upper motor neuron type destruction didn't recover completely.

Given serious and sometimes irreversible consequences of chronic inhalant dependence, early medical and psychosocial interventions seem very important.

Key words: Inhalants, cognitive impairment, psychosis, neuropathy

\section{ÖZET}

Kronik tiner bağımlıı̆ında erken başlangıçlı bilişsel yetersizlik, depresyon ve psikotik bozukluk: Olgu sunumu

Uçucu maddeler oda sıcaklığında buharlaşabilen, ağız ve burun yoluyla solunarak kullanılan, kolay bulunan, yasal ürünlerdir. Bağımılıı̆ın görülme sıklığı 14-15 yaşlarındaki hastalarda daha fazladır; yaş ilerledikçe görülme sıkliğı azalır. Uçucu madde kullanımı, sosyoekonomik olarak dezavantajlı gruplarda, suç, hapishane yaşantısı, depresyon, özkıyım girişimi, antisosyal tutumlar, okul devamsızlı̆ı, aile dağınıklı̆ı, ebeveynde bağımılık, akranlarında bağımlıık, kötüye kullanım, şiddet ya da madde kullanım öyküsü olanlarda sıktır. Kronik uçucu madde kullananlarda tıbbi ve nörolojik sorunlar fazladır. Kullanım süresinin uzaması morbidite ve mortaliteyi artırır. Bu yazıda, kendisi gibi uçucu madde bağımlısı olup sokakta beraber yaşadığı bir kardeşinin ani ölüm öyküsü bulunan, bilişsel yıkımın belirgin olduğu, psikotik ve depresif bir tablo geliştiren, yirmi dört ylllık uçucu madde bağımlısı bir vaka sunulacaktır. Hastamızda kronik uçucu madde kullanımı; santral ve periferik nöropati, bilişsel bozukluk, depresyon, psikotik bozukluk ve kaslarda üst motor nöron tipinde hasar ve hafif anemi yapmıştır. Mirtazapin ve olanzapin kullanımıla depresif bulguları ile psikotik bulguları geçen hastada, bilişsel bozukluk, nöropati, üst motor nöron tipinde kas hasarı ise devam etmiştir.

Uçucu madde bağımlılığının kronik dönemdeki ciddi ve kimi zaman geri dönüşsüz sonuçları göz önüne alındığında, hastalarda erken tıbbi ve psikososyal müdahaleler oldukça önemli gözükmektedir.

Anahtar kelimeler: Uçucu madde, bilişsel bozukluk, psikotik bozukluk, nöropati
Address reprint requests to:

Asist. Prof. Dr. Mehmet Hamid Boztaş, Abant izzet Baysal University (AiBÜ) izzet Baysal Medical School, Department of Psychiatry, 14280 Gölköy, Bolu - Turkey

Phone: +90-374-253-4656/3269

Fax: $+90-374-253-4622$

E-mail address: boztas_h@ibu.edu.tr

Date of acceptance: November 13, 2010

This case was presented in $45^{\text {th }}$ National Congress of Psychiatry (20-24 October 2009 Ankara) as a poster report.

\section{INTRODUCTION}

V olatile substances are substances which can be vaporized at room temperature and are used by oral and nasal route (1). They are preferred due to rapid, euphoric and mild drunkenness effects (1-3). Although used by inhalation nitrites, hashish, cocaine and nicotine dependencies were classified separately in DSM-IV (4). Products containing volatile substances are legal and can be found easily. For this reason, children and 
adolescents have access easily and dependence can develop in risk groups $(2,3,5)$. Volatile substance use can be as low as 6 years of age, mostly used at 14-15 years of age and decreases by advancing age $(2,5,6)$. Volatile substance dependence was higher in younger girls and increases in boys by the advancing age; in 17 years of age, prevalence of volatile substance dependence is $1.1 \%$ in girls and $2.2 \%$ in boys (5). Lifelong volatile substance usage prevalence in Turkey is $8.8 \%(7)$. Volatile substance use typically decreases in 17-19 years of age, prevalence is still higher in people working in environments having volatile substances (shoemakers, barbers etc.) (7-9).

Volatile substance abuse is frequent in socioeconomic groups with lower income, in people with history of crime or prison life, depression, suicide attempt, antisocial attitudes, school absence, family problems, substance dependence in parents and/or peers, history of abuse, violence and other substance abuse and communities isolated from environment (2,3,9-12).

Duration and frequency of volatile substance use increase morbidity and mortality (1-3). An important exception to this is sudden respiratory death (1-3). In a study, it was reported that $22 \%$ of volatile substance users who died suddenly used the substance first time (1). Sudden death is the most prevalent of deaths due to volatile substances (1). Sudden deaths are related to sudden cardiac rhythm disorders due to sensitization of myocardium to epinephrine by increasing release of catecholamines by hydrocarbons $(2,13,14)$.

Medical problems in chronic volatile substance users can be grouped as follows:

1) Muscle weakness, occasionally myoglobulinuria and rhabdomyolysis, 2) Gastrointestinal problems such as pain, nausea, vomiting, hematemesis, 3) Renal failure generally with severe electrolyte disturbances, 4) Cardiomyoptahy, 5) Liver damage, 6) Respiratory disturbances such as pulmonary hypertension, increased airway resistance and acute respiratory distress, 7) Hematopoetical disorders (increase in carboxyhemoglobin levels, methemoglobinemia, hemolytic anemia, aplastic anemia, and even acute myelocytic leukemia) $(1,2,15)$.
In chronic volatile substance use, neurological signs such as fatigue, tremor, coordination deficit, peripheral neuropathy, paresthesia, cerebellar disorders, parkinsonism, optic neuropathy, cranial neuropathy (generally V. and VII. nerves), chronic encephalopathy, dementia (dementia due to gasoline containing lead or dementia due to toluene) and mood disorders can occur (1-3).

Neuropsychiatric function disorders are due to white matter damage (1-3). Brain imaging studies showed that in chronic use there is diffuse atrophy in cerebrum, cerebellum and brain stem, ventricular dilatation and widening of sulci $(2,5,16)$. Damage in periventricular, subcortical (basal ganglia and thalamus) and white matter are observed more $(2,5,16)$ Demyelination, hyperintensity, callosal thinning and effacement of grey-white matter border were also observed $(2,5,16)$. Impairment showed in volatile substance abusers by brain imaging is higher and more severe compared to other substance abusers $(2,5)$. Bilateral reduced blood flow was observed in volatile substance abusers and this finding was related with apathy and clinical avolition (17).

In $70 \%$ of volatile substance users, a life-long mood, anxiety and personality disorder is detected (12). Risk of major depression and suicide attempt, alcohol dependence, prison experience and memory disorders are often seen among volatile substance users (18-20). Although symptoms and signs are generally reversible, especially chronic toluene use may cause changes similar to psychotic symptoms of schizophrenia. Most prevalent symptoms are delusions which are mostly paranoid and persecutive and hallucinations which are auditory and visual (19,20-24).

Volatile substance use is significantly higher in people with a street life than people without (25-27). Volatile substances are used more than other substances in people with street lives and self-harming behaviors are more frequent $(25,26)$. In parents of adolescents using volatile substances mood disorders, anxiety disorders and some personality disorders are more frequently observed (28).

Volatile substance dependence is a dependence which is seen more frequently in children and adolescents and having severe neurological and 
psychiatric consequences. It may be more severe in groups having disadvantages and in people with street lives. It may cause sudden deaths. Long-term consequences of toxic damage are important because volatile substance use decreases by age and cases with long-term effects are not frequently reported. In this case report, long-term medical, neurological and psychiatric consequences of chronic inhalant dependence was described. Initial role of psychosocial factors and long-term devastating effects in volatile substance dependence will be discussed.

\section{CASE}

A.A. was a male patient of 38 years old. He did not go to school after fourth grade and was single. He was admitted with his father.

Symptoms and history: During the last year, difficulty in walking started and progressed and he also started to fall down, forget, speak by himself and agitated. He lost pleasure of life and his participation in leisure activities also decreased. In the same time, lack of appetite, attention and concentration deficit and low self-esteem also progressed. He had 24 year long history of thinner dependence. For nearly 17 years, he used to pour $5-6 \mathrm{~kg}$ of thinner monthly to pieces of cloth and inhaled by oral and nasal route. Except for his hospitalization in psychiatry department of Bolu State Hospital for 4 months 3 years ago and 22 days of hospitalization in Istanbul, he did not give any break to thinner use.

\section{Personal History}

He was born in Istanbul and has four siblings, three of them step brothers. His mother and father were separated when he was 8 years old and he started to live with his father and grandmother. His father had alcohol dependence. His mother died when he was 10. Due to violence by their father, he and one of his brothers started to escape from home often after 10-11 years of age. Both brothers also used to escape from school as well. When he was 13, due to father's second marriage and not getting along with their step mother, he began to live in the streets with his brother. They both started to use thinner at that time. They were living with other street boys in Istanbul. At military service, he stayed in prison for 2 months due to his escape for 4 months and 10 days. He continued to inhale diesel oil and gasoline during his military service.

After the military service, he began living in the barrack of a factory with his brother. They used thinner at that period as well. At this barrack, both brothers were bitten by a dog and his brother suddenly died one month after. It was not clearly understood whether the death was due to rabies or complications of thinner. After this incident, second marriage of father was terminated and he returned back to his village in Bolu taking his children with him and began living there.

Patient used to sit at home and do not go outside except to buy thinner. In the last 10 years, he was speaking by himself or with the radio when using thinner in the beginning but also when not using it as well after. He had severe fights with his father and once stabbed his father from his chest and arm.

\section{Psychiatric examination}

His self-care was diminished and had a pale and tired appearance. Exfoliation in his palms was noticed. Thinner could be smelled from a distance. Although he tried to walk with wide steps, he had a spastic type gait. Speech amount was reduced and was difficult to understand. Spontaneous speech was also reduced. Speech frequently disintegrated and was difficult to gather. He frequently talked about the deaths of his brother and mother and required treatment.

Orientation to place, time and self was normal. Simple mathematical calculations and concentration were impaired. Immediate and remote memory were not evidently impaired but recent memory was impaired. Amount of speech was reduced. There were auditory hallucinations and they contained persecutive themes.

In neurological examination, there was horizontal nystagmus at both directions. Speech was dysarthritic. He had spastic paraparesis. Deep tendon reflexes (DTR) were brisk as $(++++)$ in lower limbs and $(+++)$ in upper 
limbs. He was walking with wide steps and had a spastic gait. Romberg test was negative.

Mild widening in cerebellar folia, widening in cerebral sulci (atrophy) and evident degeneration in

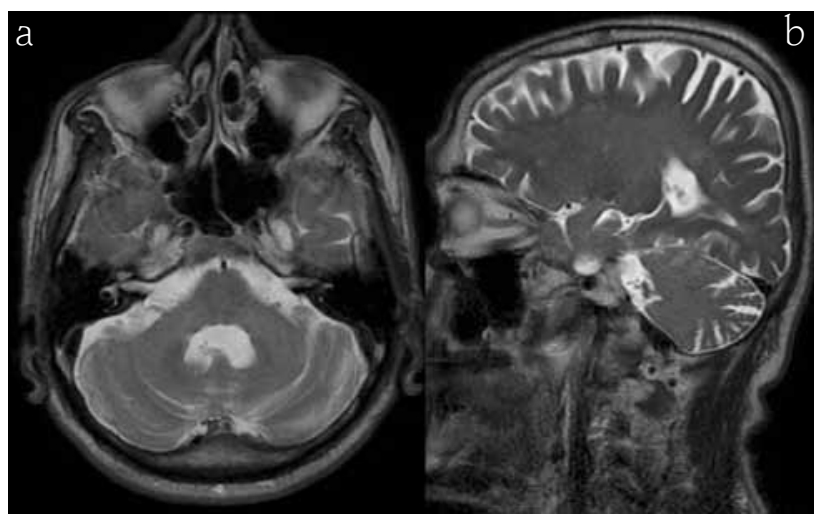

Picture 1a-b: Cranial magnetic resonance images of the chronic thinner dependence case. T2 weighted axial (a) and sagittal (b) sections showed evident atrophy in cerebellar folia and dilatation in fourth ventricle secondary to volume reduction.

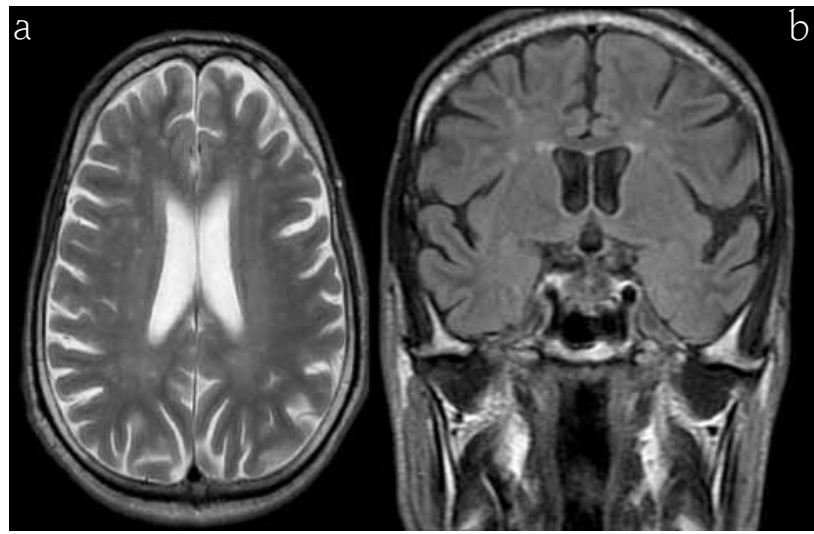

Picture 2a-b: Cranial magnetic resonance images of the chronic thinner dependence case. Non-spesific hyperintense signal changes of mostly nodular type in subcortical and deep white matter of mainly both frontal lobes at T2 weighted axial and FLAIR coronal sections. Cortical sulci are deepened and both Sylvian fissures are widened (cerebral atrophy).

white matter was detected in cranial magnetic resonance imaging (MRI), (Figure 1).

Erythrocyte sedimentation rate was $3 / \mathrm{h}$, hematocrit was 37.2, hemoglobin was $12.4 \mathrm{mg} / \mathrm{dL}$, white blood cell count was $7300 / \mathrm{mm}^{3}$ and hepatic and renal function tests were within normal limits. Electrocardiography showed normal sinusal rhythm. In electromyography (lower limb needle EMG), upper neuron type sparsing was detected.

Diagnosis: Cognitive disorder, psychotic disorder and depression due to volatile substance.

Treatment: Volatile substance use was terminated. Mirtazapin $30 \mathrm{mg} /$ day and olanzapin $5 \mathrm{mg}$ /day was started. After a month his depressive symptoms were partially improved and hallucinations were diminished. His speech was more intelligible. His gait partially improved and falls were reduced. However, his cognitive deficits, muscle weakness and disequilibrium continued.

\section{DISCUSSION}

In our patient's history, several important factors came together for the development of volatile substance dependence. First of them is the separation of his mother and father and beginning to live with his father and grandmother when he was 8 years old. Alcohol dependence of the father and his violent behaviors towards our patient facilitated uncontrolled exit of the child from home. Patient began to escape from home with his brother and returned back when father was not at home. At this time, his absence from school became permanent and he left school. He began to live in the streets and started using volatile substances at this period of his life. Living in the streets is an important risk factor of volatile substance dependence (25). His volatile substance dependent brother died suddenly and this death could not be understood by physicians. Sudden deaths are frequent in volatile substance dependents and can even occur in first use. This was proposed to be due to sensitization of myocardium to arrhytmogenic effects of catecholamines by volatile substances. Our patient felt deep sadness after his brother's death and a period which he only went out to buy thinner began. He told that he consumed $5-6 \mathrm{~kg}$. of thinner monthly by pouring it to pieces of cloth and inhale them. This amount did not change for a long time. In the last 10 years he started to speak by himself or with the radio and persecutive delusions. Our patient's neurological examination findings were 
consistent with chronic inhaling substance abuse. Permanent memory and attention deficits which were seen in periods that substance was not used, directed us towards dementia. Cranial neuropathy (horizontal nystagmus), amnesia and spastic paraparesis showed us the devastating consequences of neurological impairment. Sparsing of upper motor neuron type is the EMG finding. These damages could not be eliminated even after the termination of volatile substance use (one month after his hospitalization). His gait and dysarthria were partially improved. Borderline hemoglobin level and slightly decreased hematocrit level is expected in volatile substance dependence (9). Widening of sulci, atrophy and white matter damage seen in cranial MRI was consistent with dementia and findings due to damage in central nervous system by volatile substances $(18,20)$. Persecutive and paranoid delusions were the most prevalent of the psychotic symptoms $(2,3)$. Favorable response of the patient to atypical antipsychotic olanzapine which was recommended to be used in these patients may be due to positive effects of this agent on mood. Due to depressive mood and social withdrawal it was decided to start an antidepressant. Some of the depressive symptoms might be due to negative effect of volatile substance use. However, because of low self-esteem, loss of interest, thoughts of inadequacy and depressive mood, diagnosis of depression could not be excluded. Mirtazapin was chosen in order to be effective against lack of appetite and insomnia.

\section{REFERENCES}

1. Williams JF, Storck M, American Academy of Pediatrics Committee on Substance Abuse, American Academy of Pediatrics Committee on Native American Child Health. Inhalant Abuse. Pediatrics 2007; 119:1009-1017.

\section{Crostef}

2. Sakai JT, Crowley TJ. Inhalant-related disorders: In Sadock BJ, Sadock VA, Ruiz P (editors). Kaplan \& Sadock's Comprehensive Textbook of Psychiatry. 9th edition. Lippincott Williams Wilkins, 2009, 1341-1353.

3. Ives R. Disorders relating to the use of volatile substance. In Gelder MG, Lopez Ibor JJ, Andreasen NC (Editors). New Oxford Textbook of Psychiatry. New York: Oxford University Press, 2000, 546-550.
Acute period and intoxication symptoms of volatile substance use are well-known. However, due to diminishing risk of dependence in time, its consequences in chronic period are encountered rarely. Both volatile substance use and its dependence is reduced in years. Course of our case contains several components of a typical course of chronic volatile substance dependence. Sudden death of our patient's brother who was volatile substance dependent and was living in streets and his own clinical course with neurological, medical and mental impairment and also cognitive impairment, psychotic and depressive symptoms in the third decade of his life attract attention to devastating consequences of volatile substance use. Our patient did not go out from his house except buying thinner, could not work and communicate with other people.

Thinner dependence is increasing in our country but its long-term consequences were not reported. Most of the thinner dependent patients lose their functionalities due to negative effects of this substance. Our case showed us that chronic thinner dependence may cause dementia in third decade. Moreover, muscle weakness of upper motor neuron type seems to be important showing the relationship between thinner use and neurodegenerative process. Cognitive impairment and psychotic disorder were consistent with white matter damage. When severe and sometimes irreversible consequences of chronic volatile substance dependence are considered, early medical and psychosocial interventions seem to be important.

4. American Psychiatric Association: Diagnostic and Statistical Manual of Mental Disorders. $4^{\text {th }}$ Edition, Washington DC, American Psychiatric Association, 1994.

5. Wu LT, Ringwalt CL. Inhalant use and disorders among adults in the United States. Drug Alcohol Depend 2006; 85:1-11.

\section{Crosses}

6. Ögel K. Madde kullanım bozuklukları epidemiyolojisi. Türkiye Klinikleri Dahili Tip Bilimleri Dergisi Psikiyatri 2005; 1:61-64 (Article in Turkish)

7. Ögel K, Çorapçıŏlu A, Sir A Tamar M, Tot Ş, Doğan O,Uğuz Ş, Yenilmez Ç, Bilici M, Tamar D, Liman O. Dokuz ilde ilk ve ortaöğretim öğrencilerinde tütün, alkol ve madde kullanım yaygınlığı. Türk Psikiyatri Derg 2004; 15:112-118 (Article in Turkish). 
8. Ögel K, Tamar D, Evren C, Çakmak D. Uçucu madde kullanımının yaygınlı̆̆ı: Çok merkezli bir araştırmanın verilerinin değerlendirilmesi. Anadolu Psikiyatri Dergisi 2000; 1:220-224 (Article in Turkish).

9. Koyuncuer A. Uçucu madde entoksikasyonlu hastalara ilk yaklaşım. STED 2004; 13:366- 370 (Article in Turkish).

10. Kumar S, Grover S, Kulhara P, Mattoo SK, Basu D, Biswas P, Shah R. Inhalant abuse: A clinic-based study. Indian J Psychiatry 2008; 50:117-120.

\section{crossef}

11. Storra CL, Westergaard R, Anthony JC. Early onset inhalant use and risk for opiate initiation by young adulthood. Drug Alcohol Depend 2005; 78:253-261.

\section{Crossers}

12. Wu LT, Howard OM. Psychiatric disorders in inhalant users: results from the national epidemiologic survey on alcohol and related conditions Drug Alcohol Depend 2007; 88:146-155.

\section{crossef}

13. Vural M, Öğel K. Uçucu maddelerin kalp üzerine etkileri. Bağımlılık Dergisi 2005; 6:142- 146 (Article in Turkish).

14. Ridenour TA, Bray BC, Cottler LB. Reliability of use, abuse, and dependence of four types of inhalants in adolescents and young adults. Drug Alcohol Depend 2007; 91:40-49.

\section{crosuref}

15. Sakai JT, Hall SK, Mikulich- Gilbertson SK, Crowley TJ. Inhalant use, abuse, and dependence among adolescent patients: commonly comorbid problems. J Am Acad Child Adolesc Psychiatry 2004; 43:1080-1088.

\section{erossef}

16. Aydin K, Kircan S, Sarwar S, Okur O, Balaban E. Smaller gray matter volumes in frontal and parietal cortices of solvent abusers correlate with cognitive deficits. AJNR Am J Neuroradiol 2009; 30:1922-1928.

\section{roster}

17. Kucuk NO, Kıllı̧ EÖ, Ibiş E, Aysev A, Gençoğlu EA, Aras G, Soylu A, Erbay G. Brain SPECT findings in long-term inhalant abuse. Nuc Med Commun 2000; 21:769-773.

\section{crosser}

18. Lubman DI, Yucel M, Lawrence AJ. Inhalant abuse among adolescents: neurobiological considerations. $\mathrm{Br} \mathrm{J}$ Pharmacol 2008; 154:316-326.

\section{Crossef}

19. Filley CM, Halliday W, Kleinschmidt-DeMasters BK. The effects of toluene on the central nervous system. J Neuropathol Exp Neurol. 2004; 63:1-12.

20. Yucel M, Takagi M, Walterfang M, Lubman DI. Toluene misuse and long-term harms: A systematic review of the neuropsychological and neuroimaging literature. Neurosci Biobehav Rev 2008; 32:910-926.

\section{rossef}

21. Yucel M, Lubman DI, Solowij N, Brewer WJ. Understanding drug addiction: a neuropsychological perspective. Aust NZJ Psychiatry 2007; 41:957-968.

\section{Crossef}

22. Balster RL. Neural basis of inhalant abuse. Drug Alcohol Depend 1998; 51:207-214.

\section{erostes}

23. Altınbaş K, Saatçioğlu O, Çakmak D. Addiction and psychosis. Archives of Neuropsychiatry 2007; 44:34-40.

24. Dankı D, Dilbaz N, Okay T. Madde kullanımına bağlı gelişen psikotik bozuklukta atipik antipsikotik tedavisi: bir gözden geçirme. Bağımlılık Dergisi 2005; 6:136-141 (Article in Turkish).

25. Yüncü Z, Özbaran B, Altıntoprak E,Yıldız U, Aydın C, Coşkunol H. Sokak yaşantısı olan-olmayan madde kullanım bozukluğu olan ergenlerin klinik ve sosyodemografik özellikleri. Türkiye'de Psikiyatri 2007; 9:37-43 (Article in Turkish).

26. Aksoy A, Ögel K. Sokakta yaşayan çocuklarda kendine zarar verme davranışı ve madde kullanımı. Anadolu Psikiyatri Dergisi 2005; 6:163-169 (Article in Turkish).

27. Altındağ A., Özkan M., Oto R. İnhalanla ilişkili bozukluklar. Klinik Psikofarmakoloji Bülteni 2001;11:143-148 (Article in Turkish).

28. Zeki Y, Kesebir S, Özbaran D, Çelik Y, Aydın C. Psychopathology and temperament in parents of adolescents with substance use disorders: A controlled study. Turkish Journal of Psychiatry 2009; 20:5-13. 